\title{
Prey Selection By Tiger (Panthera Tigris Tigris) In Shuklaphanta Wildlife Reserve Nepal
}

\author{
Raj Kumar Baniya1 ${ }^{1}$, Chitra Bahadur Baniya², Pu Mou", \\ Jianping $\mathrm{Ge}^{1}$
}

\author{
${ }^{1}$ School of Life Sciences, Beijing Normal University, Beijing, china \\ ${ }^{2}$ Central Departments of Botany, Tribhuvan University, Kirtipur, Kathmandu, Nepal
}

\begin{abstract}
Predator-prey relationship indicates the status of wildlife conservation. Identifying preys and their contribution to the diets of tigers are important for making conservation meaningful. The main objective of this research was to investigate the distribution pattern of tigers and availability of their preys in the Shuklaphanta Wildlife Reserve (SWR), Far west Nepal. This research mainly focused on distribution and identification of scats, determination of prey species and factors affecting their selection. This study was conducted in SWR of $305 \mathrm{~km}^{2}$ area in Kanchanpur district, lowland, Far west Nepal. It was gazatted as Royal Shuklaphanta Wildlife Reserve in 1973. Data were collected through direct field observations and Participatory Rural Appraisal (PRA) method. Relationship between tigers and preys was determined through scats analysis. Data were analyzed with the help of Scatman and vegan through R Software. Prey and habitat selection analysis showed that chital (Axis axis) preferred sal (Shorea robusta) forests while barking (Muntiacus muntjak) and swamp (Rucervus duvauceli) deer were abundant in river sides and fireline/mixed forests respectively. Then, identified eight prey species from 65 scats of which six percent had double preys and $94 \%$ single preys. Chital constituted $30 \%$ and swamp deer $17 \%$ of the total tiger's diet. The population density of chital was the highest $\left(54.10\right.$ animals $\left./ \mathrm{km}^{2}\right)$ followed by common langur (25.27 animals $\left./ \mathrm{km}^{2}\right)$, swamp deer $\left(21.50\right.$ animals $\left./ \mathrm{km}^{2}\right)$ and hog deer $\left(16.30\right.$ animals $\left./ \mathrm{km}^{2}\right)$. Chital, hog deer and langur were preyed significantly $(P \leq 0)$ higher by tigers indicating positive selection of these species. Swamp deer was preyed significantly low $(P>0)$ indicating negative selection probably due to its large size. Tigers prefer medium to slightly large prey species like chital of about $55 \mathrm{~kg}$ body weight compared to large sized swamp deer and sambar weighing more than 150 and $210 \mathrm{~kg}$ respectively in SWR. Since, both tigers and preys are endangered due to poaching and habitat loss, regular monitoring of them is essential to develop the tiger conservation plan.
\end{abstract}

Keywords: food habitat, Panthera tigris tigris, prey selection, scat analysis

\section{Introduction}

Nepal possesses high biological diversity, and is one of the few countries in the world where the population of several keystone species have been increasing significantly following the establishment of protected areas (PA) (DNPWC 2009). Although Nepal possesses an area of just 147,181 sq km, which is merely $0.1 \%$ of the world's total landmass, but hosts almost $2 \%$ of the world's flowering plants, $8 \%$ of the world's bird species and almost $4 \%$ of the world's mammal species (Yadav 2006). Nepal is also a home to more than 100 different lingual and ethnic people. With such a vast biological repository of global significance, Nepal is undoubtedly a biological as well as a cultural hotspot that deserves special attention.

\begin{abstract}
The tiger (Panthera tigris tigris) is one of the most important mammalian species not only within Nepal but also elsewhere. Its populations in Nepal are reported mainly at Chitwan National Park (CNP), Parsa Wildlife Reserve (PWR), Bardia National Park (BNP) and Shuklaphanta Wildlife Reserve (SWR) are 91, 4, 18 and 8 respectively (Karki 2011, IUCN 2007, DNPWC 2009). Conservation of the keystone species in general and tiger at specific and its long term viability on the fragmented habitat are major concern because wildlife conservation outside PA is non-existent and the tigers are scattered in isolation without any gene flow. Thus Government of Nepal (GoN) and WWF Nepal have initiated landscape scale conservation strategies under the framework of the Tarai Arc Landscape (TAL) Program since 2004 to save the tiger population.
\end{abstract}

This article is published under the terms of the Creative Commons Attribution License 4.0 Author(s) retain the copyright of this article. Publication rights with Alkhaer Publications. Published at: http://www.ijsciences.com/pub/issue/2017-03/

DOI: 10.18483/ijSci.1221; Online ISSN: 2305-3925; Print ISSN: 2410-4477 
Frequent monitoring and inventory system are applicable to across the entire species range with the management plan necessary to prevent extinction of the tiger (Karki 2011). It requires information on habitat quality as a measure of prey abundance, which is critical for guiding tiger conservation action because tiger distribution is positively related to prey abundance particularly wild ungulates (Sunquist et al. 1999a).

Tigers are solitary, ambush hunters that actively search for prey (Wilson and Mittermeier 2009) and require more than five kilograms of flesh daily to retain their body condition (Sunquist 1981). They are capable of capturing and killing large prey, including adult male gaur, Bosgaur (Karanth and Sunquist 1995), and also take prey as small as hares (Johnsingh 1983).

Tigers' diet is highly diversed as geography (Sunquist et al. 1999b). Based on their diet breadth niche range one might infer that tigers are nonselective predators. However, morphology of tiger and their solitary hunting strategy impose limitations on prey they can capture most efficiently with minimal risk (Sunquist 2010). It suggested that the body size of prey preferred by the tigers is approximately their own size. This view has been applies to other solitary carnivores as well.

Tigers are obligate terrestrial carnivore among the mammalian assemblages (Seidensticker et al. 1999). Being an umbrella species, its effective conservation enhances survival prospects for other forms of biodiversity (Karanth 2003). The tiger Panthera tigris is also an endangered species whose demographic status is uncertain across its entire distributional range (Karanth and Nichols 1998). Because of their large body size and carnivorous diet, tigers occur at low population densities. Further, wild tiger populations are now being affected by adverse factors such as prey depletion due to overhunting (Karanth and Stith 1999), poaching, habitat shrinkage and fragmentation. In light of the rapidly degrading natural environment and severe resource depletion and manpower constraints, prioritization of conservation action in areas harboring viable tiger populations becomes vital to the long term survival of tigers (Seidensticker et al. 1999).

The fitness of a predator population also depends on an availability of its prey (Sunquist and Sunquist 1989, Karanth and Sunquist 1995, Karanth and Nichols 1998 and Karanth and Stith 1999). Studies argued that densities of tigers are governed major by an abundance of prey species. Thus, densities of tigers show a high degree of correlation with densities of prey species.
Much attention of tiger researches are found focusing on increasing their population not only in Nepal but also elsewhere. However attention on their diet, prey population and suitability of habitat are found less focused. Thus this study thus has been initiated from far west flatland natural wildlife reserve, i.e., ShuklaPhanta Wildlife Reserve of Nepal to address distribution and identification of Tiger's scats, which is a strong evidence to determine prey species and factors affecting their selection. ShuklaPhanta is one of suitable habitats for both tiger and its prey.

\section{Methods}

\section{Study Area}

Shuklaphanta Wildlife Reserve (SWR) is a protected area that lies $28^{\circ} 45^{\prime}-28^{\circ} 57^{\prime} \mathrm{N}$ to $80^{\circ} 07^{\prime}$ to $80^{\circ} 21^{\prime} \mathrm{E}$ in the Tarai of the Far-Western Region, Nepal, covering $305 \mathrm{~km}^{2}$ (118 sq miles) of open grassland, forests, riverbeds and tropical wetlands at an altitude of 174 to $1,386 \mathrm{~m}$ (571 to 4,547 ft) (DNPWC 2009). It was gazette in 1973 as Royal Shuklaphanta Wildlife Reserve (Yadav 2006). A small part of the reserve extends north of the East-West Highway to create a corridor for seasonal migration of wildlife into the Siwalik Hills. The Syali River forms the eastern boundary southward to the international border with India, which demarcates the reserve's southern and western boundary. The Indian Tiger Reserve Kishanpur Wildlife Sanctuary is contiguous in the south; this coherent protected area of 439 $\mathrm{km}^{2}$ represents the Tiger Conservation Unit (TCU) Shuklaphanta-Kishanpur, which covers a 1.897 $\mathrm{km}^{2}$ block of alluvial grasslands and subtropical moist deciduous forests.

The area was a favorite hunting ground for Nepal's ruling class and was declared as Royal Hunting Reserve in 1969. In 1973 the area was gazette as Royal Shuklaphanta Wildlife Reserve, initially comprising $155 \mathrm{~km}^{2}$, and extended to its present size in the late $1980 \mathrm{~s}$. A buffer zone of $243.5 \mathrm{~km}^{2}$ was declared in May 2004.

The climate of the region is subtropical monsoonal with mean annual rainfall of $1,579 \mathrm{~mm}$ that occurs from June to September and is highest in August. The winter months of December and January are fairly cold with daytime temperatures of $7-12^{\circ} \mathrm{C}$ and occasional frost. From February onwards temperatures rise up to $25^{\circ} \mathrm{C}$ in March and reaching $42^{\circ} \mathrm{C}$ by end of April. When the first premonsoon rains reach the area in May, humidity increases.

The prevalent vegetation of the reserve is Shuklaphanta- grassland, which covers about $50 \mathrm{~km}^{2}$ in area and is the largest patch of continuous grassland in Nepal. The main grass species include Imperata 
contortus. Khagra Reed (Phragmites karka) and Saccharum spontaneum grow in the marshes of the seven small lakes. The dominant forest type is Sal, Khair and Sissoo grow alongside rivers. The extensive open grasslands and wetlands around the lakes of the reserve are habitat for a wide range of faunal species. In the rivers, lakes and ponds, 27 fish species, the globally threatened Mugger crocodile and Indian Rock Python have been recorded as well as the monitor Lizard, Indian Cobra and Common Krait. Current checklists include 46 species of mammals, 18 of which are protected under CITES such as the Bengal Tiger, Leopard, Sloth Bear, Swamp Deer, Asian Wild Elephant and Hispid Hare. Greater One-horned Rhinoceros were translocated from Chitwan National Park to establish a third viable population in the country.

A total of 423 bird species has been recorded (Weaver 1990) in the reserve that supports the highest population of Bengal Floricans in Nepal. It is the western limit of Swamp Francolin, Jerdon's Bushchat, Rufous-rumped Grass bird, Chestnutcapped Babbler and Jerdon's Babbler; the northwestern limit of Yellow-eyed Babbler; the eastern limit of Finn's Weaver and the most important regular wintering site of Hodgson's Bush chat.

\section{Field surveys}

A total of 31 different locations (Annex 1) had been identified as probable places to collect the Tiger's scat inside the Shuklaphanta Wildlife Reserve. These locations were visited on Feburary and March 2012. Altogether 68 scats were collected randomley along fire lines, river bank, foot trails and grassland bordering them and other locations known for tigers. Among them three scats were discarded because of unidentifiable hair and hooves. Tiger scats are generally distinguished from those of leopards based on their size (tiger scats are larger), appearance (tigers scats have a lower degree of coiling) and other evidence in the form of associated pugmarks and scraps. The fact that tigers drop their scats at relatively larger distances between two consecutive constrictions within a single piece of scat can be used to distinguish between scats of these two felid species (Biswas and Sankar 2002). Each collected scat was air dried, stored in paper envelopes and individually labeled, with collected date and location, including latitude and longitude.

Those collected air dried scats were dipped into the slightly tepid water for about 2 hours in the plastic bowl. After that the scats were grinded thoroughly by hand and were washed several times with cold water by using $212 \mu, 415 \mu$ and $850 \mu$ sieves respectively. The remaining clean ungulate bones and hairs were air dried and kept into the sample zip locked plastic bags. The bags were labeled according to their collected dates and locations.

For good quality permanent slides, hairs were washed in tepid water, rinsed in distilled water followed by both in absolute alcohol (95\%). Thus washed hairs were used to prepare cuticular and medullar slides. The slides were prepared by following the method of (Teerink 1991, De Marinis and Asprea 2006 and Bonnin 2008).

\section{Data Analysis}

Information and data collected both from the field; wildlife Reserve authorities, local people and laboratory analyses were analyzed using statistical software such as vegen in R, CanoDraw (Šmilauer 2002), Scatman (Hines and Link 1994) and MS Excel (Windows 7).

\section{Results}

Locations of Tigers' scats at different habitats in Shuklaphanta Wildlife Reserve

I identified five ecological habitats viz. Riverine area of Mahakali River, fireline with mixed forest, Sal forest, fireline with grass and foot trail with sal forest within these locations (Figure 1) based upon the Tiger's scats collection. I did not find any scats in the Churia region. The Global Information System (GIS) map prepared after combining this information revealed that the core forest zones: Shuklaphanta, Barkula, Sundari Phanta, Dhaknaghat and Singhpur of SWR had the higher number of scats (> 40).

\begin{abstract}
Abundance of scat of prey species in their habitats Based on the appearance and disappearance of individual prey species at each sample scat and their ecological habitats such as forest types and elevation revealed that altitude and fireline with mixed forest variables (Figure 2) significantly represented the First axis of Redundancy Analysis (RDA). Abundance of Rucervus duvaucelii (Swamp deer) showed significantly higher towards the fireline with mixed forest. The fireline with mixed forest was located towards the maximum altitude as per dataset and RDA (Figure 2). Significant abundance of Axis axis (Chital) denoted towards sal forest and low altitude. Significantly high abundance of Muntiacus muntjak (Barking deer) represented by Riverine area of Mahakali river along the Second axis of RDA (Figure 2). Likewise, significantly high abundance of Sus scrofa (Wild boar), Axis porcinus (Hog deer), Cervus unicolor (Sambar), Hystricx indica (Porcupine) and Presbytis entellus (Common langur) defined by foot trail with sal forest and fireline with grass habitats.
\end{abstract}

\section{Composition of prey species in scats}


Among 65 scats $12(18 \%)$ scats were found with bones and hooves of prey species. In addition, four scats $(6 \%)$ contained two prey items and the remaining $76 \%$ scats contained single prey item. Scat analysis revealed 69 prey individuals of eight prey species (Figure 2). Chital was the most preferred menu by the Tiger since it repeated 30 times among total scats (Figure 3). These identified prey species included Chital, Swamp deer, Barking deer, Sambar, Porcupine, Wild Boar, Hog deer, and Common langur.

\section{Characteristics of prey species found in scats}

Chital showed slightly larger sized prey species (55 $\mathrm{kg}$ ) but the relative number of individual species killed was the highest (34.25) (Table 1). Sambar had the largest estimated weight per animal $(212 \mathrm{~kg})$ in SWR but the relative number of individual species killed was low (2.80) as compared with other prey species (Table 1). Similarly, Common langur and Porcupine had relatively small sized prey species $(8$ $\mathrm{kg}$ and $9 \mathrm{~kg}$ respectively) but the relative numbers of individual found in the scats were the same (11.04).

\section{Status of prey species found in Shuklaphanta Wildlife Reserve}

I found published information only on four prey species regarding their density (number of individuals per square $\mathrm{km}$ ) and their standard error density from SWR. According to the information, Chital had the highest density (54.10) with standard error (14.30) followed by hog deer with the lowest density (16.30) with standard error (3.20) (Table 2). Chital had been killed in the highest number by tigers. This information had been incorporated in the Scatman Software to understand the relationship between prey and predator.

\section{Prey selection}

The prey selectivity in this study is related to the prey species killed by tigers. Among these prey species, Chital $(P \leq 0)$, Hog deer $(P \leq 0)$ and Common Langur $(P \leq 0)$ were preyed significantly higher than expectation based on their availability which indicated positive selection of these prey species by tigers. Swamp deer $(P>0)$ was preyed significantly low as compared to their availability indicating its negative selection to this species. This was also attributed with the body size of prey animal. Swamp deer had an estimated body weight of $159 \mathrm{~kg}$ (Table 1) showed non-significant adjusted p-value $(P>$ $0.11)$.

Chital showed the highest significant adjusted $\mathrm{P}$ Value (0.00) after the Bootstrap replications (200) by Scatman indicated that prey species had been strongly and significantly killed by the Tiger in Shuklaphanta Wildlife Reserve (Table 3).

\section{Distribution of scats in different habitats}

Based on distribution of Tiger's scats in this study five ecological habitats viz. riverine area of Mahakali river, mixed forest fireline, sal forest, grassland fireline and sal forest foot trails were found best which was similar with finding of (Lamichhane 2011). Abundance of Swamp deer showed significantly higher towards the mixed forest fireline zone. This fireline forest was found significantly located towards higher altitude as per the present dataset and RDA. Chital favored much the sal forest and low altitude which is also suggested by (Biswas and Sankar 2002). Barking deer found abundantly towards riverside area of Mahakali River. Likewise, Wild boar, Hog deer, Sambar, Porcupine and Common langur found favored much high foot trails with sal forest and fireline with grass habitats. Not finding of scats from the Churia region may reveal that either prey species do not find Churia or tigers do not prefer such habitats.

\section{Prey species constituting the diet of Tiger}

The tiger population in SWR in 2007 declined sharply leaving just seven tigers (DNPWC 2007). This decline was attributed to the security problems during political conflict resulting more poaching of tigers in SWR. The sample size of scat analysis for this study was 65 , which was similar with the sample size suggested by (Biswas and Sankar 2002), who also suggested that analyzing of at least 60 scats for understanding the pattern of prey used by tigers will be good enough. Based on the present results after scat analysis, the principal prey species of tigers were Chital, Swamp deer, Barking deer, Sambar, Porcupine, Wild boar, Hog deer and Common langur. (Biswas and Sankar 2002, Grey 2009 and Lamichhane 2011) also found the similar results in their studies.

(Karanth and Sunquist 1995 and Grey 2009) classified prey species into small $(<20 \mathrm{~kg})$, medium $(20-50 \mathrm{~kg})$ and large (>50 kg) based on their body mass. The average weight of highly killed prey species such as Chital and Hog deer of SWR was estimated as 40 and $55 \mathrm{~kg}$ respectively, which means tigers of SWR showed significantly high selection of medium to slightly large sized prey animals compared to very large sized animals weighing 159 $\mathrm{kg}$ of Swamp deer and $212 \mathrm{~kg}$ of Sambar found in SWR.

About $94 \%$ tigers were found satisfied by the single prey species, while $6 \%$ tigers were found preferred and hunted double prey species. This was similar with the result reported by (Biswas and Sankar 2002 and Grey 2009), who also found that multiple prey items rarely in scats of large predators such as tigers, but relatively common in smaller carnivores.

\section{Discussion}


The diet of SWR tigers, the frequency of occurrence, relative biomass killed and relative numbers of individuals killed were calculated. Generally, percent occurrence is considered as more appropriate method of quantifying the diet of carnivores than frequency of occurrence as it accounts for more than one of a given item being found in a scat, (Karanth and Sunquist 1995, Biswas and Sankar 2002, Bagchi et al. 2003, Grey 2009, Thapa 2011 and Lamichhane 2011). In this study both the approaches showed similar results.

According to Taylor (1976 cited by Grey 2009), model of predation predicts that aggregation of prey constrains the predator, gregarious nature of Chital makes the species less vulnerable to predation than other solitary preys (Schaller 1967, Sunquist and Sunquist 1989). Chital habitually associate in aggregations of 20 to 100 individuals on forest edges and grasslands and are considered to be the most gregarious among ungulates (Dinerstein 1980, Schaller 1967, Mukherjee et al. 1994a, Grey 2009). SWR tigers preying upon Chital were highly significant $(P \leq 0)$ indicating positive selection of Chital by tigers. In addition, population density of Chital in SWR was higher (54.10 individuals per $\mathrm{km}^{2}$ ) compared with other prey species, which was one of the main reasons for higher predation of Chital by tigers. Another reason could be grass coverage better suited for ambush hunter like tiger to kill Chital. (Karanth and Sunquist 1995) reported that higher the density of prey species greater the encounter rate with the tiger, which ultimately increases the chance of predation. This principal was not applicable in Swamp deer $(P>0)$, which was the most abundant prey species in SWR. Less predation of Swamp deer by tigers was attributed to its large size compared with other prey species available in SWR. In Bardia National Park (BNP), study done by (Grey 2009), Chital contributed 46 times $(58.98 \%)$ more than that of Swamp deer (1.28\%) and its biomass contribution was 18 times more than Chital (Lamichhane 2011). In Chitwan National Park (CNP) also found that more Chital $(46.31 \%)$ were preyed by the tigers compared with other prey species. It means tiger prefers to hunt more medium to slightly large sized animals compared with small and very large sized animals, because Hog deer is medium sized prey species and its population in SWR was low, but was hunted $(P \leq 0)$ significantly by the tigers. Another reason for hunting more Hog deer by tigers could be its solitary in nature. (Schaller 1967) also reported that Hog deer are normally solitary occurring in two or three individuals. Similarly, Common langur $(P \leq$ 0 ) in SWR was preyed more than their availability, which was attributed to their solitary nature with occurrence in large groups.
There was no evidence of Nilgai killing in tiger scats during the study period in SWR. This was probably due to fires in grasslands and forests or may be low in numbers, which makes tiger visible to Nilgai. (Schaller 1967) and Karanth and Sunquist 1995) reported that Nilgai are found mostly in open areas near human settlements or relocated village sites, but this types of habitat are unsuitable for tigers to hunt. In addition, Nilgai is very large sized animals, which also makes it unsuitable for tigers to hunt.

\section{Relationship between Tigers and prey population}

According to the study conducted at Bardia National Park (Grey 2009), Chital contributed 46 times $(58.98 \%)$ more than that of Swamp deer (1.28\%) and its biomass contribution was 18 times more (Table 4) than others. Similarly, (Lamichhane 2011), in Chitwan National Park (CNP) found the number of Chital contributed more $(46.31 \%)$ than the other species.

The Chital density in BNP is nearly twice higher than the number in SWR and doubles that of CNP. But the density of Swamp deer in SWR is 20 times higher than in BNP. Also the biomass contribution in BNP is double of both CNP and SWR and in SWR the biomass contribution of Swamp deer is 14 times higher than BNP.

Tigers of SWR have prey Chital significantly high compared with other prey species. This attributed the high density of Chital in SWR. (Karanth and Sunquist 1995) also reported that high density of Chital in an area may increase their encounter rate by the tiger, which ultimately increases the chance of predation. Other factors determining prey selection by tigers included appropriate body weight and size of Chital and their habitats or living environment.

\section{Composition of species and habitats}

The Redundancy Analysis (RDA) between prey species and their surrounding environment showed that sal forest was suitable habitat for Chital and Riverine for Barking deer. Similarly Sambar was found more on fireline with mixed forest. Some of the observations showed that fireline with grass were suitable for some prey species like Common langur. These results showed that the tiger predating more on Chital spent more time in sal forest searching its prey.

\section{Acknowledements}

This study was partially funded by National Trust for Nature Conservation (NTNC), Lalitpur, Nepal. Thanks to Dr. Khadga Basnet, and faculty members of the Central Department of Environmental Science Tribhuvan University, Kathmandu, Nepal for their 
cooperative effort. We also appreciate ECO Beijing, China for their valuable suggestions.

\section{References}

1. Ackerman, B.B., Lindzey, F.G., Hemker, T.P., 1984. Cougar food habits in southern Utah. Journal of Wildlife Management. 48: 147-155.

2. Adhikari, S., Khadka, A., 2009. Study on relative abundance and distribution of tiger base (ungulates) in Khata Coridor, Bardia National Park, Kathmandu University. Journal of Science and Engineering Technology. 5: 112-135.

3. Anonymous, 2008. Annual Report 2007-2008, Government of Nepal, ministry of forest and soil conservation, Department of National Park and Wildlife Conservation.

4. Bagchi, S., Goyal, S.P., Sankar, K., 2003. Prey abundance and prey selection by tiger (Pantheratigris) in semi-arid, deciduous forest in western India. Zoological Society London 20: 285-290.

5. Biswas, S., Sankar, K., 2002. Prey abundance and food habit of tigers (Panthera tigris tigris) in Pench National Park, Madhya Pradesh, India. Journal of Zoology London. 256: 411-420.

6. Bonnin, L., 2008. Prey selection by tiger (Panthera tigris tigris) in the Karnali floodplain of B ardia National Park, Nepal. Journal of Zoology London. 23-39.

7. Braack, E.O., 2005. African trans frontier conservation area, real benefits to agriculture and rural development.

8. De Marinis, A.M., Asprea, A., 2006. Hair identification key of wild and domestic ungulates from southern Europe. Wildlife Biology. 12: 305-320.

9. Dinerstein, E.C., Loucks, A., Heydlauff, E., Wikramanayake, G., Bryja, J., Forrest, J., Ginsberg, S., Klenzendorf, P., Leimgruber, T., O’Brien, T., 2006. Setting Priorities for the Conservation and Recovery of Wild Tiger; 2005-2015; A User's Guide WWF, WCS, Smithsonian and NFWF-STF, Washington, D.C. - New York.

10. Dinerstein, E., 1980. ecological survey of Royal Bardia Karnali Wildlife Reserve. Part III: Ungulate Populations. Biological Conservation. 18: 5-37.

11. DNPWC, 2007. Anual report, Department of National Park and Wildlife Conservation/GoN, Kathmandu, Nepal.

12. DNPWC, 2009. Anual report, Department of National Park and Wildlife Conservation/GoN, Kathmandu, Nepal.

13. Grey, J., 2009. Prey Selection by Tigers (Pantheara tigris tigris) in the Karnali Flood Plain of Bardia National Park, Nepal. (M.Sc.Thesis). Imperial College, London.

14. Hariahar, A., Kurien, A.J., Pandar, B., Goyal, S.P., 2007. Response of tiger population to habitat with ungulate prey and human disturbance in Rijaji National Park, Uttarakhanda, India. (Final technical report, 2007). Wildlife Institute of India, Dhradun.

15. Hayward, M.W., Je drzejewski, W., Je drzewska, B., 2012. Prey preferences of the tiger Panthera tigris. Journal of Zoology, London. 286: 221-231.

16. Hines,J.E.,Link,W.A.,1994.ScatmanSoftware.Retrievedon02/ 01/2011.htt://search.nasa.gov/search/search.jsp?nasaInclude= Scatman.

17. Jnawali, S.R., Wegge, P., 1993. Space and habitat use by a small re-introduced population of greater one-horned rhinoceros (Rhinoceros unicorns) in Bardia National Park in Nepal- a preliminary report. Presented at the International Rhino Conference, San Diego.

18. Johnsingh, A.J.T., 1983. Large mammalian prey-predators in Bandipur. Journal of Bombay Natural Historical Society. 80: 1-57.

19. Karanth, K.U., 2003. Tiger ecology and conservation in the Indian subcontinent. Journal of Bombay Natural Historical Society. 100: 169-189.

20. Karanth, K.U., Madhusudan, M.D., 2002. Mitigation HumanWildlife Conflicts in Southern Asia. In; Making Parks Work, Strategies for Preserving Tropical Nature. 250-264.
21. Karanth, K.U., Nichols, J.D., 1998. Estimation of tiger densities in India using photographic captures and recaptures. Ecology 79: 2852-2862.

22. Karanth, K.U., Stith, B.M., 1999. Prey depletion as a critical determinant of tiger population viability. In Riding the tiger: tiger conservation in human dominated landscapes: 100-113 Siedensticker, J., Christie, S. and Jackson, P. (Eds). Cambridge University Press.

23. Karanth, K.U., Sunquist, M.E., 1995. Prey selection by tiger, leopard and dholes and hole in tropical forests. Journal of Animal Ecology. 64: 439-450.

24. Karki, J.B., 2011. Occupancy and abundance of Tigers and their prey in the Terai Arc Landscape, Nepal. (P.hd. Thesis). Wildlife Institute of India, Dehradun, Uttarakhand.

25. Karki, J.B., Jnawali, S.R., Shrestha, R., Pandey, M.B., Gurung, G., Thapa (Karki), M., 2009. Tiger and their prey base in Terai Arc Landscape Nepal. Government of Nepal, Ministry of Forest and Soil Conservation, Department of National Parks and Wildlife Conservation and Department of Forest.

26. Lamichhane, S., 2011. prey selection by Panthera tigris of Chitwan National Park. M.Sc. thesis: Submitted to the Kathmandu University.

27. Link, W.A., Karanth, K.U., 1994. Correcting for overdispersion in tests of prey selectivity. Ecology 75: 24562459.

28. Miquelle, D., Smirnov, E.N., Merrill, T.W., Myslenkov, A.E. Quigley, H.B., Hornocker, M.G., Schleyer, B., Seidensticker, J., Christie, S., Jackson, P., 1999. Hierarchical spatial analysis of Amur tiger relationships to habitat and prey. In Riding the tiger: tiger conservation inhuman-dominated landscapes: 71-99. Seidensticker J., Christie S. \& and Jackson P. (Eds). Cambridge: Cambridge University Press. Zoological Society London.

29. Miquelle, D., Smirnov, E.N., Quigley, H.B., Hornocker, M.G., Nikolayev, I.G., Matyushkin, E.N., 1996. Foodhabits of Amur tigers in Sikhote-Alin Zapovednik and theRussianthe Russian Far East, and implications for conservation. Journal of Wildlife Research. 1: 138-147.

30. Mukherjee, S., Goyal, S.P., Chellam, R., 1994a. Refined techniques for the analysis of Asiatic lion panthera leo persica scats. Acta Theriologica. 39: 425-430.

31. Oli, M.K., Taylor, I.R., Rogers, E., 1994. Snow leopard Panthera uncia prredation of livestock: an assessment of local perceptions in the Annapurna Conservation area, Nepal. Biological Conservation. 68: 63-68.

32. Sankar, K., Qureshi, Q., Nigam, P., Malik, P.K., Sinha, P.R., Mehrotra, R.N., Gopal, R., Bhattacharjee, S., Mandal, K. Gupta, S., 2010. Monitoring of reintroduced tigers in Sariska Tiger Reserve, Western India: preliminary findings on home range, prey selection and food habits. Tropical Conservation Science. 3 (3): 301-318.

33. Schaller, G.B., 1967. The deer and the Tiger. University Chicago press, Chicago.

34. Seidensticker, J., Christie, S., Jackson, P., 1999. Overview in Riding the tiger: tiger conservation in human-dominated landscapes: 1-3. Cambridge: Cambridge University Press.

35. Shrestha, M., 2004. Relative Ungulate abundance in a fragmented landscape; Implication for Tiger Conservation. A thesis submitted to the faculty of the Graduate School of the University of Minnesota for the partial fulfillment of the requirement for the degree of Doctor of Philosophy.

36. Sinclair, A.R.., Byrom, A., 2006. Understanding ecosystem dynamics for conservation of biota. Journal of Animal Ecology. 75: 64-79.

37. Smilauer, P., 2002. CanoDraw for Windows 4.0.

38. Smith, J.L.D., Ahearn, S.C., McDougal, C., 1998. Landscape analysis of Tiger distribution and habitat quality in Nepal. Conservation Biology. 12: 1338-1346.

39. Sunquist, M.E., 1981. The social organization of tigers (Panthera tigris) in Royal Chitawan National Park, Nepal. Smithson Contribution to Zoology. 336: 1-98. 
40. Sunquist, M.E., 2010. Tigers: ecology and behavior. In Tigers of the world: 19-33. Tilson, R.L. and Nyhus, P.J. (Eds). San Diego: Elsevier.

41. Sunquist, M.E., Karanth, K.U., Sunquist, F.C., 1999a. Ecology, behaviour and resilience of the tiger and its conservation needs. In Tigers of the world: the science, politics and conservation of Panthera tigris: 5. Tilson, R.L. and Nyhus, P.J. (Eds). New York: Academic Press.

42. Sunquist, M.E., Karanth, K.U., Sunquist, F.C., 1999 b. Ecology, behavior and resilience of the tiger and its conservation needs. In: J. Seidensticker, Sarah Christie and Peter Jackson (eds). Riding the tiger: tiger conservation in human dominated landscapes.

43. Sunquist, M.E., Sunquist, F.C., 1989. Ecological constraints on predation by large felids. In: Gittleman, J. L., (ed). Carnivore behaviour, ecology and evolution. Cornell University Press, Ithaca.

44. TAL, 2004. The Terai Arc Landscape Bengal Tiger in the Himalayas, shadow.

45. Teerink, B.J., 1991. Hair of West-European Mammals. Cambridge: Cambridge University.

46. Ter Braak, C.G., 2002. CANOCO- a FORTRAN program for canonical community ordination by (partial) (detrended) (canonical) correspondance analysis, principal component analysis and redundancy analysis. Version 4.5. Wageningen.

47. Thapa, T.B., 2011. Habitat suitability evaluation for Leopard (Panthera pardus) using Remote Sensing and GIS in and around Chitwan National Park, Nepal. (P.hd.). Wildlife Institute of India, Chandrabani, Dehradun.

48. Weaver, D.J., 1990. A survey of Bengal Floricans (Houbaropsis bengalensis) at Royal Suklaphanta Wildlife Reserve and Royal Bardia National Park, western Nepal.

49. Wegge, P., Odden, M., Pokhrel, C.P., Storass, T., 2009. Predator prey relationship and responces of ungulates and their predators to the establishment of protected area. A case study of Tigers, Leopords and their prey in Bardia National Park, Nepal. Biological Conservation. 142: 189-202.

50. Wilson, D.E., Mittermeier, R.A., 2009. Handbook of the mammals of the world. Vol. 1. Carnivores. Barcelona: Lynx Edicions.

51. Yadav, H.K., 2006. Density, Biomass and Distribution of Tiger's Prey Species in Shukla Phanta Wildlife Reserve, Western Lowland, Nepal. Thesis submitted to Kathmandu University.

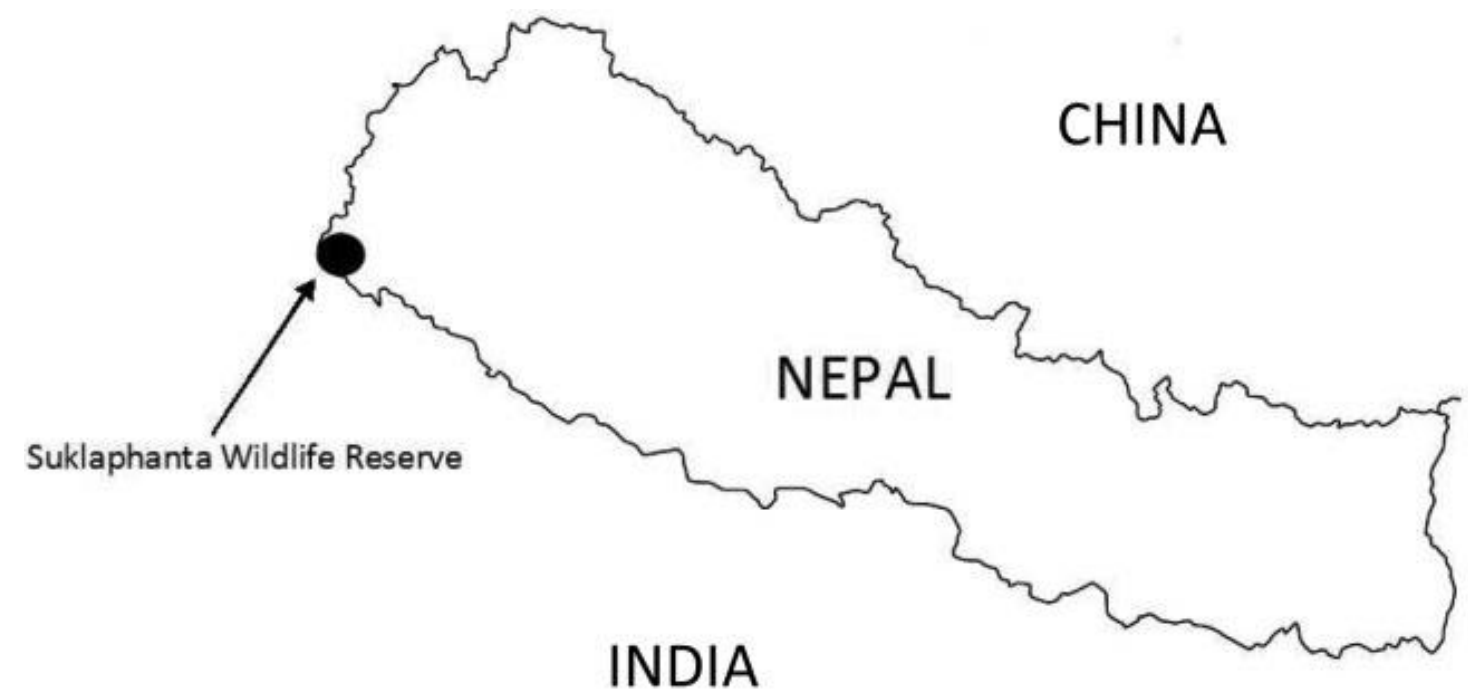

Figure1. Location map of Shuklaphanta Wildlife Reserve 


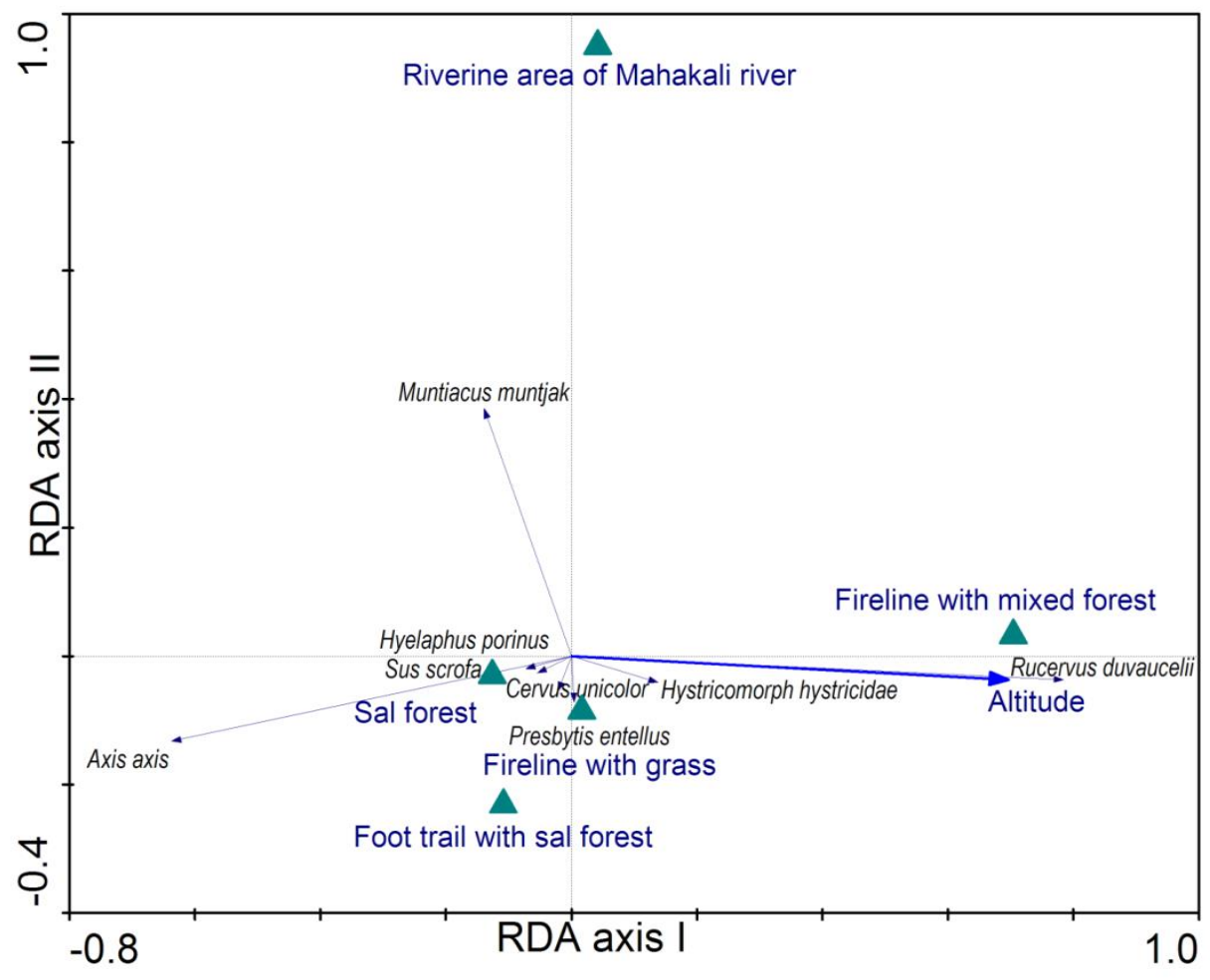

Figure2. Redundancy Analysis (RDA) among prey species and their habitats

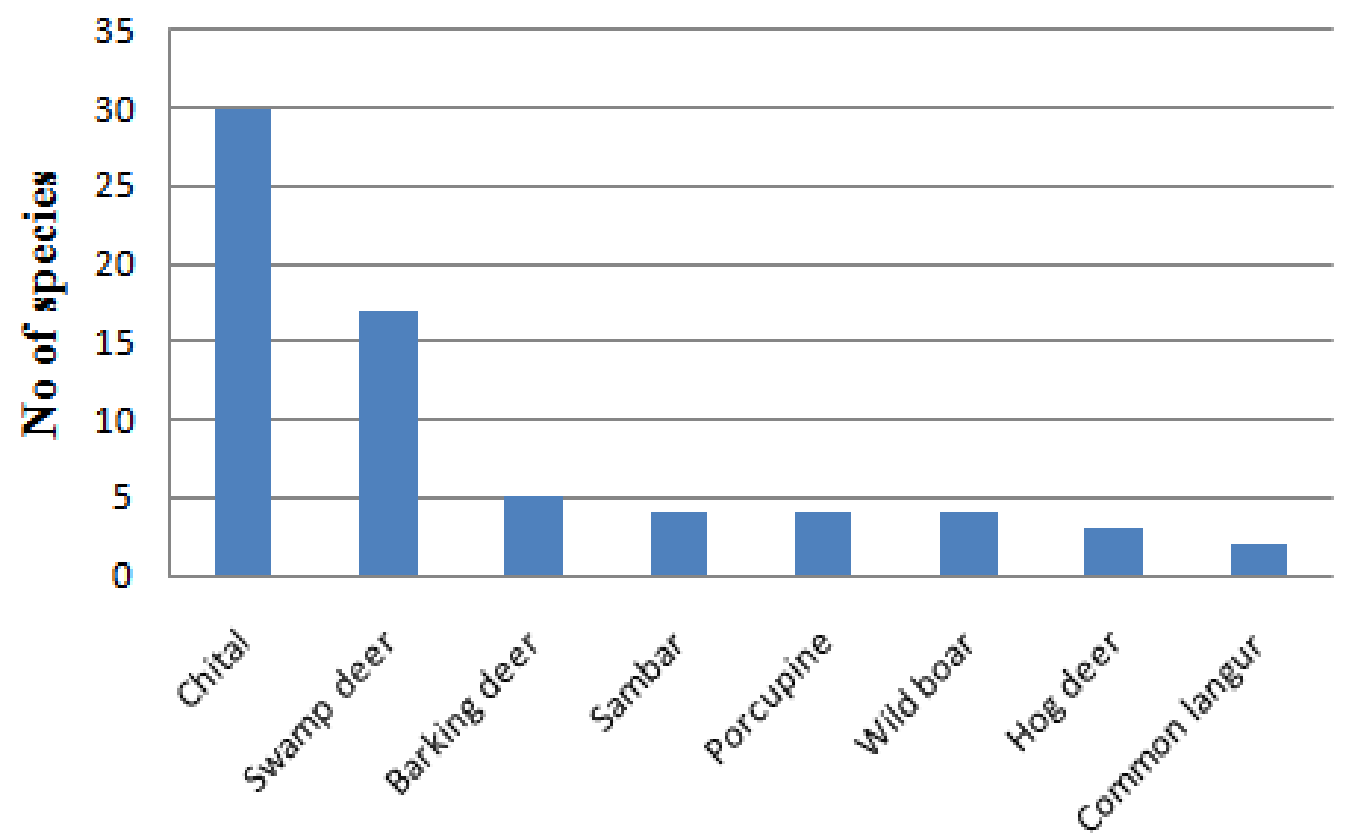

Figure3. Composition of Prey Species 


\begin{tabular}{|c|c|c|c|c|c|c|c|}
\hline & & & A & B & $\mathrm{C}$ & D & $\mathbf{E}$ \\
\hline Prey & $\begin{array}{l}\text { No. of } \\
\text { Prey } \\
\text { items }\end{array}$ & $\begin{array}{l}\% \text { of pray } \\
\text { occurrence }\end{array}$ & $\begin{array}{l}\text { Frequency } \\
\text { of } \\
\text { occurrence } \\
(\%)\end{array}$ & $\begin{array}{l}\text { Estimated } \\
\text { Weight (X) } \\
\text { Kg }\end{array}$ & $\begin{array}{l}\text { Correction } \\
\text { factor Y(kg } \\
\text { of prey/scat) }\end{array}$ & $\begin{array}{l}\text { Relative } \\
\text { Biomass } \\
\text { Killed } \\
(\%)\end{array}$ & $\begin{array}{l}\text { Relative } \\
\text { No. of } \\
\text { Ind. } \\
\text { Killed } \\
(\%)\end{array}$ \\
\hline Chital & 30.00 & 44.12 & 45.40 & 55.00 & 30.9 & 34.30 & 34.25 \\
\hline $\begin{array}{l}\text { Swamp } \\
\text { deer }\end{array}$ & 16.00 & 23.52 & 25.40 & 159.00 & 7.55 & 37.10 & 12.70 \\
\hline $\begin{array}{l}\text { Barking } \\
\text { deer }\end{array}$ & 5.00 & 7.35 & 7.70 & 20.00 & 2.68 & 4.00 & 11.04 \\
\hline Sambar & 4.00 & 5.88 & 6.20 & 212.00 & 9.40 & 11.30 & 2.80 \\
\hline Porcupine & 4.00 & 5.88 & 3.10 & 9.00 & 2.26 & 1.40 & 11.04 \\
\hline Wild Boar & 4.00 & 5.88 & 4.61 & 38.00 & 8.98 & 8.01 & 11.60 \\
\hline $\begin{array}{l}\text { Common } \\
\text { Langur }\end{array}$ & 2.00 & 2.94 & 3.10 & 8.00 & 2.30 & 1.40 & 11.04 \\
\hline Hog deer & 3.00 & 4.41 & 4.61 & 40.00 & 2.93 & 2.61 & 5.52 \\
\hline Total & 68 & 100 & 100 & & & 100 & 100 \\
\hline
\end{tabular}

Table1. Prey species composition in tiger scats $(n=65)$ and their percentage of occurrence, frequency of occurrence and calculation of relative biomass and number of prey individual killed by tigers based on the scats collection.

$\mathrm{D}=(\mathrm{AxC}) / \sum(\mathrm{AxC}): \mathrm{E}=(\mathrm{DxB}) / \sum(\mathrm{DxB})$

Where, $A=$ Frequency of occurrence $(\%)$

$\mathrm{B}=$ Estimated weight $(\mathrm{kg})$

$\mathrm{C}=$ Correction factor $(\mathrm{kg}$ of prey/scat)

$\mathrm{D}=$ Relative biomass killed $(\%)$ and $\mathrm{E}=$ Relative no of individual killed $(\%)$

\begin{tabular}{lllll}
\hline Prey & Scat frequency & Scat Production & Density & S.E. Density \\
& & $(\lambda \mathbf{i}=\mathbf{X} / \mathbf{Y})$ & $($ Individual/sq.km.) & (Individual/sq.km.) \\
\hline Chital & 29.50 & 3.90 & 54.10 & 14.30 \\
Swamp deer & 16.50 & 7.55 & 21.50 & 10.80 \\
Hog deer & 3.00 & 9.40 & 16.30 & 3.20 \\
Common Langur & 2.00 & 8.98 & 25.27 & 4.80 \\
\hline
\end{tabular}

Table2. Prey species, scat frequency, scat production, and estimates of prey densities with associated standard error (SE) for each prey species.

Where $\mathrm{Y}$ is the biomass of prey consumed $(\mathrm{kg})$ to produce a single field collectable scat and $\mathrm{X}$ is the average body weight of the prey species $(\mathrm{kg})$. 
Table3. Testing for prey selectivity from scat data in table 3 (Bootstrap replications set at 200 and the variability in scat production rate set at $40 \%$ of the mean level; sign+ and - indicates preference and avoidance respectively).

\begin{tabular}{|l|l|l|l|l|l|l|}
\hline Prey & $\begin{array}{l}\text { Observed } \\
\text { Scat } \\
\text { Frequency }\end{array}$ & $\begin{array}{l}\text { Estimated } \\
\text { Expected }\end{array}$ & Chi-Square & $\begin{array}{l}\text { Unadjusted } \\
\text { P-Value }\end{array}$ & $\begin{array}{l}\text { Adjusted } \\
\text { P-Value }\end{array}$ & Standard \\
Error \\
\hline Chital & 29.50 & 14.28 & 22.5247 & 0.000 & $0.0000^{+}$ & 0.0000 \\
\hline $\begin{array}{l}\text { Swamp } \\
\text { deer }\end{array}$ & 16.50 & 10.99 & 3.5252 & 0.060 & $0.1167^{-}$ & 0.0055 \\
\hline Hog deer & 3.00 & 10.37 & 6.5762 & 0.010 & $0.0170^{+}$ & 0.0006 \\
\hline $\begin{array}{l}\text { Common } \\
\text { Langur }\end{array}$ & 2.00 & 15.36 & 16.6286 & 0.000 & $0.0001^{+}$ & 0.0000 \\
\hline
\end{tabular}

Table4. Density and Biomass in CNP, BNP and SWR.

\begin{tabular}{|l|l|l|l|l|l|l|}
\hline & \multicolumn{3}{|l|}{ Biomass contribution (\%) } & \multicolumn{3}{l|}{ Ungulates density (individual/km²) } \\
\hline & CNP & BNP & SWR* & CNP & BNP & SWR* \\
\hline Chital & 38.32 & 63.40 & 34.30 & 43.90 & 86.41 & 54.10 \\
\hline $\begin{array}{l}\text { Swamp } \\
\text { deer }\end{array}$ & - & 2.95 & 37.10 & - & 0.22 & 21.50 \\
\hline
\end{tabular}

SWR*- Yadav (2006), CNP- Lamichhane (2011). BNP- Grey (2009) 